DOI 10.37882/2500-3682.2021.03.17

\title{
КРИЗИС СЦИЕНТИЗМА: ПРИЧИНЫ ВОЗНИКНОВЕНИЯ
} И ПОСЛЕДСТВИЯ

\section{SCIENTISM CRISIS: CAUSES AND CONSEQUENCES}

\section{Skopa}

Summary: The article analyzes the ideological position, which is based on the idea of scientific knowledge as the highest cultural value and a determining factor in a person's orientation in the world. On the basis of fundamental works on the philosophy of scientific knowledge, the crisis of scientism is determined, the reasons for its occurrence and consequences are determined. On the basis of V.V. Kazyutinsky's research, the factors that contributed to the weakening of the scientistic worldview orientation are identified, which he combined into three groups: epistemological, philosophical-anthropological and sociocultural. It has been determined that modern science forms a diversifying idea of scientific and technological progress, its role and significance in the conditions of a modern post-industrial society, and this pushes scientists to the opportunity to talk about the emergence of the next ideological crisis of civilization.

Keywords: scientism, scientific and technological revolution, paradigm, postmodernism, worldview.
B современном обществе научное познание не рассматривается ни как феномен культуры, ни как нечто высшее. Технократические подходы действующих систем заставили изменить научные тенденции, а вместе с тем сформировать новое отношение к науке и ее результатам. Во многом это прослеживается как в гуманитарных областях знания, так и естественно-научных.

В исторической ретроспективе XIX столетие можно охарактеризовать как время сильнейшего академического оптимизма, когда идея Ф. Бэкона «Scientia potentia est» получила реализацию в жизнь, с технологическим прогрессом синтезировала вера на реализацию глобального счастья.

Превращение научных знаний в непосредственную производительную силу общества, невиданные ранее темпы научно-технического прогресса изменили облик современного мира в большей степени, нежели политические и экономические потрясения последних десятилетий [5, с. 20]. В данной ситуации нельзя не привести высказывание В.И. Вернадского о приоритетной роли научной мысли в преобразовании биосферы в ноосферное состояние и о невиданном ранее возрастании значения наук в общественной жизни всего человечества

\author{
Скопа Виталий Александрович \\ Д.и.н., профессор, Алтайский государственный \\ педагогический университет, г. Барнаул \\ sverhtitan@rambler.ru
}

Аннотация: В статье анализируется идейная позиция, в основе которой лежит представление о научном знании как о наивысшей культурной ценности и определяющем факторе ориентации человека в мире. На основе фундаментальных работ по философии научного познания определяется кризис сциентизма, определены причины его возникновения и последствия. На основе исследований Казютинского В.В. выделены факторы, способствовавшие ослаблению сциентистской мировоззренческой ориентации, которые он объединил в три группы: эпистемологические, философско-антропологические и социокультурные. Определено, что современная наука формирует диверсифицирующее представление о научно-техническом прогрессе, его роли и значимости в условиях современного постиндустриального общества, а это подталкивает ученых к возможности говорить о зарождении очередного мировоззренческого кризиса цивилизации.

Ключевые слова: сциентизм, научно-техническая революция, парадигма, постмодернизм, мировоззрение.

[3]. Казалось бы, осуществилась идея сциентистов, и современной науке по силам осуществить ранее не разрешимую философией и религией задачу: сделать всех людей счастливыми. Тем не менее, реальность развеивает оптимистические иллюзии [2, с. 141].

Однако в конце XX столетия все большую силу начинает набирать интеллектуальное движение, представители которого утверждают, что человечество находится в эпохе формирования новой культурной матрицы, в которой наука не играет доминирующей роли и сама становится иной [1, с. 39]. По словам П. Фейерабенда, идеолога принципа эпистемологического анархизма, привилегированное положение науки в обществе способствовало формированию бездушного технократического общества и представляло собой настоящую угрозу демократии, так как вместо независимых исследований общество получило научный бизнес - результат сращивания научного авторитета с капиталом, паразитирующий на социуме [12, с. 143]. Таким образом, многовековая дискуссия об автономности науки и о свободе последней от ценностных норм приобретает новое звучание. На сегодняшний день, как никогда становится актуальным вопрос «о расставании с духом сциентизма?!». Так, В.В. Казютинский выделяет целый ряд факторов, 
способствовавших ослаблению сциентистской мировоззренческой ориентации, которые он условно объединил в три группы: эпистемологические, философско-антропологические и социокультурные [10, с. 94].

Если говорить об эпистемологических факторах, то необходимо вспомнить традиционные критерии отличия науки от других сфер духовной культуры. Как известно, В.И. Вернадский, большой оптимист в отношении перспектив дальнейшего человечества на основе научно-технического прогресса, указывал, что «есть одно явление, что описывает академическую тенденцию и отличает академические итоги и научные заключения... от утверждений философии и религии, - это бесспорность академических выводов, утверждений, понятий, заключений». [3, с. 174] Автор подчеркивал общеобязательность и бесспорность научной истины, чем наука «резко отличается от любого другого знания и духовного проявления человечества - не зависит ни от эпохи, ни от общественного и государственного строя» [3, с. 186]. Таким образом, высшим судьей, выносящим в науке приговор теоретическим конструкциям, является экспериментальное начало - многократная воспроизводимость результатов в различных условиях и различными исследователями. Данная тенденциозность не придает научному понятию целостности, а вместе с тем размывает академические устои и научные традиции.

Прошедшее столетие можно с полным основанием наименовать периодом академических (научных) революций, повергнувших к перемене научной парадигмы и выработке новой науки, не соответствующей многим критериям академического знания, упомянутых выше [7, с. 340]. В данном случае можно утверждать не только об утрате наглядности, наблюдаемой в квантовой механике, где «действие метода определяет процесс познания» и, таким образом, размывается представление о реальности и рациональном мышлении, а «красота уравнений важнее, чем их согласие с экспериментом» [4, с. 188]. Помимо этого, многие современные научные концепции принципиально недоказуемы.

Что касается философско-антропологических и социокультурных факторов, то можно отметить следующее.

Во-первых, мы можем говорить о решительной критике позиций сциентизма. Так, М. Стенмарк отмечает, что сциентизм сформировал в современном западном обществе целый ряд представлений: существует только та реальность, к которой наука имеет доступ; наука - самая ценная часть человеческого знания или культуры; одна лишь наука способна объяснить и заменить мораль и религию [14, с. 62-64]. Тем не менее, объяснять возникновение религии и морали исключительно с точки зрения естественного отбора, редуцировать человеческую личность до «набора воды, кальция и органических молекул» или сводить всю реальность исключительно к доступной для физических приборов материи выглядит слишком смело в свете выше сказанного [9, с. 220].

Во-вторых, современный постмодернизм решительно стремится ограничить ценность научной истины, утверждая, что наука не превосходит естественную проницаемость человеческой расы и требуя уравнять науку в правах с другими сферами духовной культуры, в частности, мифологией [11, с. 47]. Если П. Сорокин отдавал приоритет научной истине перед всеми остальными:, то для П. Фейерабенда «демократическая оценка выше «Истины» и мнения экспертов» $[6,8]$.

B-третьих, усиливается негативная оценка успехов научного познания (в первую очередь в ряде прикладных исследований) со стороны общества. Так, по результатам проведенных исследований, более $60,0 \%$ респондентов полагают, что наука во многом несет в себе опасность, а около 70\% утверждают, что ученые пренебрегают этикой в процессе исследования [11, с. 92]. Исходя из этого можно констатировать, что многовековая дискуссия об автономности науки и о свободе последней от ценностных норм приобретает новое звучание.

Во многом современная наука формирует диверсифицирующее представление о научно-техническом прогрессе, его роли и значимости в условиях современного постиндустриального общества. А это во многом подталкивает ученых к возможности говорить о зарождении очередного мировоззренческого кризиса цивилизации. Глубинные основы кризисных явлений в мировой науки следует видеть в том, что наука стала использоваться для эксплуатации природы. Так, Г. Галилей сопоставлял эмпирическую основу с испанским сапогом, в который «нужно зажать природу, чтобы она открыла свои тайны»; И. Мичурин писал: «Мы не можем ждать милостей от природы, взять их у неё - наша задача». Во многом данные установки привели к изменению или даже деформации понимания науки и ее ценности.

Многие катастрофические сценарии (применение оружия массового поражения; экологический кризис цивилизации; модификация природы человека) связывают с научными достижениями и это подталкивает к выдвижению обвинений науки, которая «не смогла обеспечить духовный прогресс и не в состоянии представить какие-либо точные прогнозы на будущее» [7].

Исходя из этого можно отметить, что в социуме наука утрачивает одну из важнейших функций - прогностическую функцию знания; наступает разочарование в существовании объективных научных истин и бесспорности правильно сделанных научных выводов.

Не лишенные основания претензии высказываются 
в адрес целого ряда направлений исследований прикладного характера. Наибольшие опасения вызывают разработки в области ядерной энергетики, генной инженерии и других биотехнологических направлений [11, с. 108]. Современные технологии могут предоставить потенциальную возможность модифицировать личностные характеристики человека как в результате воздействия психотропных препаратов, так и в процессе преобразований генотипа. Последнее представляется вполне допустимым в свете достижений последних лет в области генетики человека, показавших, что многие черты характера и формы поведения, такие как агрессивность и застенчивость, повышенная сексуальность и супружеская верность, смелость и трусость, - генетически детерминированы. Подобные открытия порождают сразу две проблемы. Первая заключается в том, что различные формы асоциального и аморального поведения получают «индульгенцию» ценой признания, что «Ноmo sapiens» по своей сути ничем не отличается от других биологических видов. Вторая проблема состоит в соблазне решить целый ряд социальных проблем путем незначительных модификаций генома, не принимая при этом во внимание сложные взаимодействия между различными элементами единой системы [13, с. 221].
В целом потребность в стабильности, предсказуемости будущего закономерна, но синергетическое представление о глобальной эволюции, лежащее в основе постнеклассической науки, утверждает, что развитие мира - процесс непредсказуемый, так как из любого кризисного состояния есть несколько альтернативных путей. Стационарный мир И. Ньютона не признается более научной общественностью, но значительная часть населения продолжает чувствовать себя частью этого мира. В мире неравновесных открытых систем, бурном, динамичном и непредсказуемом, человек чувствует себя неуютно, так как подсознательно стремится к стабильности и уверенности в завтрашнем дне. «Не дай Вам Бог жить в эпоху перемен» - заявляли древнекитайские мудрецы [10, с. 198]. К сожалению, времена не выбирают - стремительно развивающаяся на наших глазах глобализация, сопровождаемая невиданными ранее в истории темпами научно-технического прогресса, представляет серьезный вызов традиционной культуре и мировоззрению. А на повестке дня встают вопросы о необходимости синтеза естественнонаучного и гуманитарного знания, а также других важнейших сфер духовной культуры, что будет во многом определять будущую перспективу научного познания.

\section{ЛИТЕРАТУРА}

1. Бабанин А.Ф. Введение в общую теорию мироздания. М.: Едиториал УРСС, 2004. 188 с.

2. Берков В.Ф. Философия и методология науки. М.: Новое знание, 2004. 357 с.

3. Вернадский В.И. Биосфера и ноосфера. М.: Рольф, 2002. 288 с.

4. Гейзенберг В. Философские проблемы атомной физики. М.: Едиториал УРСС, 2004. 314 с.

5. Гордеева И.В. Наука в эпоху постмодернизма: рациональные знания и лженаучные идеи // Материалы интернет-конференции 16-19 июня 2008 г. «Философия науки. Методология науки. История науки». Ижевск, 2008. С. 11-25.

6. Ефремов Ю.И. Вглубь Вселенной. Звезды, галактики и мироздание. М.: Едиториал УРСС, 2003. 255 с.

7. Казютинский В.В. Ценностные ориентации современного космизма и прогнозы будущего техногенной цивилизации // Философия, наука, цивилизация. M., 1999. С. 337-348.

8. Кара-Мурза С.Г. Идеология и мать ее наука. М.: Алгоритм, 2002. 151 с.

9. К Кохановский В.П. Философия и методология науки. Ростов н/Д Феникс, 1999. 392 с.

10. Универсальный эволюционизм и глобальные проблемы /РАН. Ин-т философии; Отв. ред.: В.В. Казютинский, Е.А. Мамчур. М.: ИФ РАН, 2007. 253 с.

11. Философия естественных наук / Под ред. А.С. Лебедева. М.: Академический проект, 2006. 173 с.

12. Фейерабенд П. Наука в свободном обществе / пер. с англ. А.Л. Никифорова. М.: АСТ МОСКВА, 2010. 378 с.

13. Хорган Дж. Конец науки. М.: Амфора, 2002. 306 с.

14. Stenmark M. Scientism: Science, Ethics and Religion. Burlington: Ashgate Publishing Company, 2000. 152 p. 